Article

\title{
Towards a Sustainable Model of Innovative Work Behaviors' Enhancement: The Mediating Role of Employability
}

\author{
Jol Stoffers ${ }^{1,3,4, * \mathbb{C}}$, Beatrice van der Heijden ${ }^{2,3,5,6,7} \mathbb{D}$ and Ilse Schrijver ${ }^{1}$ \\ 1 Research Centre for Employability, Zuyd University of Applied Sciences, 6131 MT Sittard, The Netherlands \\ 2 Institute for Management Research, Radboud University, 6500 HK Nijmegen, The Netherlands \\ 3 Faculty of Management, Open University of the Netherlands, 6419 AT Heerlen, The Netherlands \\ 4 Research Centre for Education and the Labour Market (ROA), Maastricht University, \\ 6211 LM Maastricht, The Netherlands \\ 5 Department of Marketing, Innovation and Organisation, Ghent University, 9000 Ghent, Belgium \\ 6 Business School, Hubei University, Wuhan 430062, China \\ 7 Kingston Business School, Kingston University, Kingston upon Thames, London KT2 7LB, UK \\ * Correspondence: jol.stoffers@zuyd.nl
}

Received: 27 October 2019; Accepted: 16 December 2019; Published: 24 December 2019

check for updates

\begin{abstract}
In this mixed methods study, a moderated mediation model predicting effects of leader-member exchange (LMX) and organizational citizenship behaviors (OCB) on innovative work behaviors, with employability as a mediator, has been tested. Multi-source data from 487 pairs of employees and supervisors working in 151 small and medium-sized enterprises (SMEs) supported our hypothesized model. The results of structural equation modelling provide support for our model. In particular, the benefits of close relationships and high-quality exchanges between employee and supervisor (LMX), and fostering individual development as a result of employees' OCB have an indirect effect on innovative work behaviors through positive effects on workers' employability. Innovative work behaviors depend on employees' knowledge, skills, and expertise. In other words, enhancing workers' employability nurtures innovative work behaviors. In addition, we found a moderation effect of organizational politics on the relationship between employability and innovative work behaviors. Secondly, qualitative methods focusing on experiences of the antecedents and outcomes of employability were used to complement our quantitative results. All in all, this study has important consequences for managerial strategies and practices in SMEs and call for an awareness of the dysfunctional effect of perceived organizational politics.
\end{abstract}

Keywords: leader-member exchange (LMX); organizational citizenship behaviors (OCB); innovative work behaviors; employability; perceived organizational politics; small and medium-sized enterprises (SMEs); mixed methods sequential explanatory study; multi-source data

\section{Introduction}

Organizations that experience growth frequently launch new product features, offer better services, and incorporate more efficient and effective internal processes [1]; in other words, increasing and maintaining market share requires sustainable organizational innovation [2]. Moreover, innovation is vital for organizations, especially for SMEs, to deal with challenges related to the Sustainable Development Goals introduced by the United Nations (UN) [3] and to promote humane and productive organizations [4]. Innovative behaviors are strongly connected with sustainability [4]; when employees are innovative, organizations meet the changing demands of their customers better [5], and employees' sustainable innovative work behaviors guarantee prolonged customer benefits [6]. Among the three 
dimensions of organizational sustainability, the social dimension (i.e., related to employees and their work behaviors) has received less attention when compared to the economic and environmental dimensions of sustainability [7]. Notwithstanding the exemplary work by Witt [8], who, building upon social learning processes, already stressed the importance of collectively shared interpretation patterns and the importance of leadership aimed at inducing firm members to take responsibility and to engage in creative problem-solving and to be innovative, we argue that there is more work needed in order to unravel the social dimension of organizational sustainability. In a similar vein, Erkut [9], who found empirical support for the importance of interactions of employees with an organization's customers and the feeling of self-empowerment, emphasized the need to nudge members to take responsibility for innovativeness. Therefore, we focus on several aspects related to the social dimension that are deemed to be important in the light of enhancing innovative work behaviors in firms. In particular, after conducting a thorough literature study and interviews with highly innovative professionals and entrepreneurs [10], we decided to move the work in this field forward by adopting a perspective-taking framework [11-13]. Perspective-taking is one of the drivers of sustainable business behaviors and organizational sustainability [14,15]. To understand how innovative work behaviors can be enhanced, predictor variables that all refer to the ability to relate to others (for instance, one's supervisor), in particular, the ability to perceive someone else's thoughts, feelings, and motivations (e.g., perspective-taking), and to engage with one another in the day-to-day practice, were hypothesized. In particular, perspective-taking refers to the ability of employees to empathize with someone else and to see things from their perspective. Indeed, Davis [16] found that perspective-taking, among others, is positively correlated with social competences, being an important ingredient of employability (see also $[17,18])$, which has been defined as the extent to which employees are able and willing to remain working now and in the future [19].

In order to enhance our knowledge in this scholarly field, we will investigate a model wherein leader-member exchange (LMX) and organizational citizenship behaviors (OCB) are incorporated as factors that are associated with employability, and wherein employability, in turn, is assumed to contribute to innovative work behaviors. To the best of our knowledge, so far, these variables have never been related to each other in a mediation model (with employability being the mediator) predicting innovative work behaviors. As such, this study increases the empirical knowledge that builds upon perspective-taking theory $[12,13]$.

To conclude, the study that is reported in this article may make an important contribution to both the employability and SME literature. Despite the substantial increase in literature on employability over the years, there is a lack of research into the way employability is embedded in the SME context (see also [20]). In addition, by focusing on a better understanding of the social dimension of organizational sustainability, this empirical work adds to a better understanding of how organizations can cope with the need to be innovative and deal with the challenges related to the Sustainable Development Goals. In order to do so, this study builds upon the theoretical framework of perspective-taking and has three particular objectives. Using a quantitative approach, firstly, we will identify predictor variables (LMX and OCB) that may influence innovative work behaviors directly and indirectly through employability. Secondly, we will examine whether perceived organizational politics play a moderating role in the proposed model (see Figure 1). Thirdly, we will investigate certain appraisal effects (as a result of paired-samples comparisons, based on our multi-source data; employee and his/her supervisor) such as the halo effect, leniency, and hardiness. Next to the quantitative study that has been explained above, our study aims to increase our insights in the social dimension of organizational sustainability by using a qualitative approach that focuses on obtaining a better understanding of SME employees' and supervisors' experiences of the antecedents and outcomes of employability building upon perspective-taking theory [13] as an underlying framework. More insight into the role of perspective-taking can guide us in formulating management practices that are aimed at stimulating valuable interactions in the workplace. 


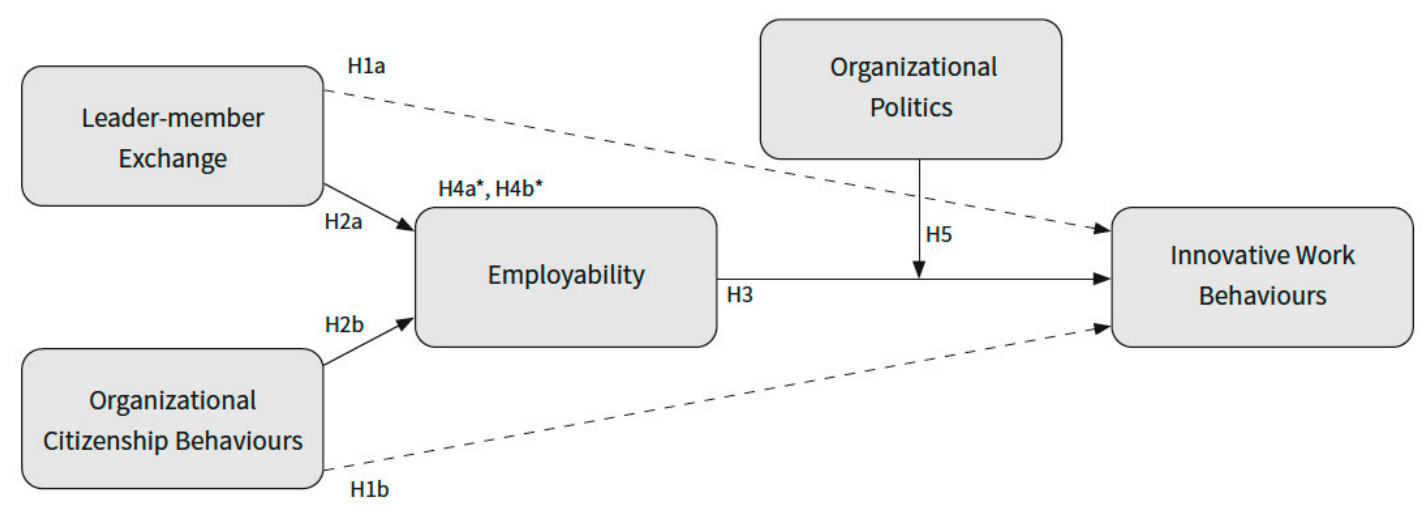

Figure 1. A sustainable model of innovative work behaviors' enhancement. Note: H4a and H4b are mediation hypotheses.

In the following section (i.e., the conceptual framework) an overview of the literature on the variables under study and their relationships will be given, followed by the formulation of our hypotheses. Afterwards, an overview of the research methodology (mixed methods sequential explanatory study) will be outlined. Next, the results of the pair-wise comparisons of employee and supervisor ratings will be presented. Structural equation modelling (SEM) will be performed in order to confirm the factor structure of the measurement instruments and to test our hypothesized moderated mediation model. Furthermore, qualitative methods (in-depth interviews and a focus group) will be used to explain and to complement our quantitative results. Finally, our findings will be discussed and we will explore several possible future research perspectives. We will conclude with practical implications of our study.

\section{Conceptual Framework}

In this section we explain the research model, the variables under study, and their underlying relationships expressed in our research hypotheses. We propose that relationship quality with supervisors (that is, LMX) is associated with sustainable innovativeness [7,21,22]. It is also hypothesized that employees who portray extra-role behavior, which comprises delivering more than their official roles and job descriptions prescribe [23] (also referred to as OCB [24]), are more likely to behave innovatively as they invest more in the development of their skills. After all, we argue that in order to achieve a continuous flow of innovations, employees must be willing and competent to innovate $[25,26]$. Extant research that uses a competency approach to employability [17] supports the predictive validity of competencies in the light of innovative work behaviors [27,28].

Moreover, the hypothesized mediation model that will be studied comprises perceived organizational politics as a possible moderator. Perceived organizational politics is an important phenomenon because of its influence on work outcomes [29]. Previous literature suggests that politics interfere with normal organizational processes and might harm innovation at both the individual and organizational levels [30]. In this contribution, we will focus on the influence of perceived organizational politics on the relationship between employability and innovative work behaviors.

\subsection{Predictors of Innovative Work Behaviors: $L M X$ and $O C B$}

Regarding the first predictor of innovative work behaviors, i.e., LMX, earlier research suggests that mutual trust, respect, and obligation signify the true essence of relationships formed between leaders and their subordinates [31,32]. LMX models represent paramount theoretical and empirical approaches to organizational leadership [32,33] and explain influences on exchange relationship quality and work-related outcomes such as performance and innovative work behaviors $[6,21,26]$. In particular, the LMX measure incorporates the evolution of leader-follower relationships and followers' satisfaction with their leaders, and addresses a facet of leadership that is absent from other theories-awareness that 
leaders develop various types of relationships with individual followers [34,35]. Hence, LMX emphasizes reciprocal social exchanges that develop, nurture, and sustain the relationship between a supervisor and their employee. The relationship between both parties is low-quality when it is based on employment contracts (out-groups), or high-quality when it extends beyond formal employment contracts (in-groups) [33]. Employee innovative work behaviors transcend a worker's formal role expectations and are not recognized explicitly [36]. However, Janssen [37] argues that employees act more innovatively to extend their job demands when they perceive that leaders will reward their efforts fairly. Under these circumstances, they perceive a balance between work effort and supervisor encouragement, and consequently respond more innovatively [38]. Based on the outline given above, we formulate the following hypothesis:

\section{Hypothesis 1a (H1a). Leader-member exchange correlates positively with innovative work behaviors.}

The second predictor of innovative work behaviors that is taken into account refers to OCB. Innovative work behaviors among employees protect an organization's chances to survive and prepare it to cope with evolving environments [1]. Increasingly, organizations ought to rely on a workforce that is eager to contribute to innovativeness, and that does not limit itself to its formal role requirements. Organ [24] identifies five types of OCBs-altruism, conscientiousness, sportsmanship, courtesy, and civic virtue-and suggests that OCBs are voluntary. Consequently, although context plays a role [39], individual behaviors are personal choices that influence organizational effectiveness [40] and sustainability [41,42]. Podsakoff et al. [39] posit that individual initiative is a form of OCB, defining it as voluntary behaviors beyond what is formally required or expected, such as creativity, which are found to improve individual or organizational performance. Based on the outline given above, we hypothesize the following:

Hypothesis 1b (H1b). Organizational citizenship behaviors correlate positively with innovative work behaviors.

\subsection{Towards a Mediation Model of Innovative Work Behaviors}

De Jong and Den Hartog [1] suggest that innovative work behaviors expand an organization's innovative abilities. Highly qualified employees who possess the competencies, resources, and technologies to adopt innovation are essential in the work context since their qualities make imitation difficult, and permit organizations to sustain competitive advantages [43]. Indeed, earlier research suggests that employees' innovative behaviors, defined as the creation, introduction, and application of new ideas that benefit performance [37], are required for organizational endurance [44]. Farr and Ford [45] define innovative work behaviors as an individual's behaviors that achieve initiation and intentional introduction (within a work role, group, or organization) of new and useful ideas, processes, products, or procedures [44]. Janssen [37,46] argue that innovative work behaviors link to stages during innovation (i.e., idea generation, promotion, and realization), and, therefore, innovative work behaviors are creative behaviors, but simultaneously include managed promotion and implementation of creative ideas [47].

Continual changes to markets and working conditions require employees to adapt to the demands of new situations by focusing on learning new skills and acquiring state-of-the-art knowledge [48]. Ideally, employees possess the skills, expertise, and knowledge to interact with stakeholders inside and outside the organization, both now and in the future [25]. Rothwell and Arnold [49] state that workers' employability comprises aspects such as sustainability of work, qualifications, and future-oriented perspectives. Moreover, employees should also assimilate occupational expertise and subsequently apply it to new areas of work [50], which increase both their employability (or career potential) [51] and (future) innovative work behaviors. Employability refers to "continuously fulfilling, acquiring or creating work through the optimal use of competences" [17] (p. 453), and is needed to guarantee a permanent acquisition and fulfilment of employment inside and outside the organization over 
time [52]. Van der Heijde and Van der Heijden [17] conceptualize employability at the individual level, combining occupational expertise [53] with four types of generic competencies. Research in various contexts and among professionals working in disparate occupations supports their operationalization of employability into five dimensions: (a) occupational expertise, (b) anticipation and optimization, (c) personal flexibility, (d) corporate sense, and (e) balance [19]. Van der Heijde and Van der Heijden's [17] operationalization accords with Fugate, Kinicki, and Ashforth [54], who define employability as "a form of work-specific active adaptability that enables workers to identify and realize career opportunities" (p. 16).

Regarding the predictive validity of LMX, sufficient interactions with supervisors offer employees the opportunity to obtain adequate information and support when tackling challenging tasks and responsibilities. Howell and Hall-Meranda [55] argue that high-quality LMX correlates positively with employee performance and employability dimensions. In a similar vein, Van der Heijden et al. [56] also suggests that a positive relationship with a supervisor enhances their subordinate's employability. Therefore, we hypothesize the following:

Hypothesis 2a (H2a). Leader-member exchange correlates positively with employability.

Consequences of OCBs have not been studied as thoroughly in comparison with the attention for their antecedents [39], and previous research on the effects of OCBs focused only on intended beneficiaries (e.g., individuals, groups, and organizations); it has not examined consequences for those engaging in OCBs [57]. For example, supervisors appear to give higher performance ratings to those engaged in OCBs [39]. Spitzmuller et al. [57] found that prosocial behaviors facilitate individual development in subsequent stages of life [58]. However, such results should be interpreted with caution since social psychological research differs from that conducted in organizational contexts [57]. Podsakoff et al. [39] suggest that developing individual character is a dimension of OCBs (see also [59]), including employees' voluntary behaviors that improve knowledge, skills, and abilities to perform better in current and future positions, and that expand contributions to an organization [59]. Podsakoff et al. [39] reports ways in which OCBs influence organizational effectiveness positively: assisting with training and acclimatizing new colleagues, reducing intergroup conflicts, permitting supervisors to delegate, volunteering to take on new responsibilities or learn new skills, and participating in meetings. We argue that such behaviors associate positively with one's employability, given the built-up arsenal of knowledge and skills as a result of participating in the tasks distinguished above. Therefore, we hypothesize the following:

Hypothesis $\mathbf{2 b}(\mathbf{H} \mathbf{2 b})$. Organizational citizenship behaviors correlate positively with employability.

Delaney and Huselid [60] argue that employee participation and empowerment, combined with extensive employee training and related management practices, have a positive effect on innovation as expressed, for example, in the capacity to introduce new products [61]. Innovative work behaviors [37] depend on employees' knowledge, skills, and expertise [62,63]. Therefore, enhancing employees' competencies and career potential nurtures innovative work behaviors. Extant research suggests that enhancing employability contributes to innovative work behaviors [64], and therefore we hypothesize the following:

Hypothesis 3 (H3). Employability correlates positively with innovative work behaviors.

Hypothesis 4a (H4a). Employability (partially) mediates the relationship between leader-member exchange and innovative work behaviors.

Hypothesis $4 \mathbf{b} \mathbf{( H 4 b ) . ~ E m p l o y a b i l i t y ~ ( p a r t i a l l y ) ~ m e d i a t e s ~ t h e ~ r e l a t i o n s h i p ~ b e t w e e n ~ O C B ~ a n d ~ i n n o v a t i v e ~}$ work behaviors. 


\subsection{Perceived Organizational Politics as a Moderator}

Innovation is one of the drivers of sustainable development of organizations and may be hindered by organizational politics [65]. Organizational politics appear in all organizations [29,66], and perceptions of these serve as a central dimension that employees use during sense-making at work [67]. Organizational politics are multi-dimensional, subjective, context-specific psychological phenomena; individuals respond to what they perceive and not necessarily to what is objectively real [68]. What matters is how employees perceive political behaviors in an organization, how inaction by other members represents career-advancing opportunities, and how others apply pay and promotions politically [69].

Ferris et al. [69] developed a conceptualization of organizational politics in which an individual's perceptions of events is interpreted as a view of reality, encouraging cognitive and behavioral responses [66]. They define politics as "a social influence process in which behaviour is strategically designed to maximize short-term or long-term self-interest, which is either consistent with, or at the expense of others' interests" (p. 145). Parker et al. [67] argue that employees who perceive a higher degree of organizational politics view their organizations as being less supportive of innovation. In particular, a work atmosphere characterized by trust, openness, and collaboration enhances innovation [70], but organizational politics impair these attributes and interfere with innovation [71,72]. Otherwise stated, employees' knowledge and skill development that result in innovative ability are hindered in negative work atmospheres wherein the learning climate (e.g., interactions, communication, and co-operative structures) is experienced to be suboptimal [73]. Therefore, we hypothesize the following:

Hypothesis 5 (H5). Perceived organizational politics negatively moderate the relationship between employability and innovative work behaviors.

Figure 1 portrays all hypothesized relationships between the variables under study.

As explained in the introduction section, next to testing our hypothesized research model (see Figure 1) using a quantitative approach, our study further aims to achieve a better understanding of SME employees' and supervisors' experiences of the antecedents and outcomes of employability building upon perspective-taking theory $[12,13]$ as an underlying framework. For this reason, three research questions (RQ) have been formulated that guided the qualitative analyses in this contribution:

RQ 1. How do participants (employees and supervisors of SMEs) experience the importance of the ability to relate to others (perspective-thinking), for instance to one's supervisor (LMX), or the importance to engage in extra-role behaviors $(\mathrm{OCB})$, and do these antecedents contribute to sustainable innovation within the organization?

$R Q$ 2. Do participants experience that the ability to empathize with someone else and to see things from their perspective (perspective-thinking) influence social competences and development of skills (being an important ingredient of employability), and do they experience that the ability to empathize also contributes to innovative work behaviors?

RQ 3. Do participants experience organizational politics and do they believe that these might harm innovation efforts? Do participants experience that their knowledge and skill development, which is supposed to contribute to sustainable innovation, is hindered by a negative work atmosphere and a suboptimal learning climate?

\section{Methods}

A sequential explanatory mixed methods design, i.e., qualitative methods explaining and complementing quantitative results, was used (QUAN $\rightarrow$ qual. [74]). Our design also offers the opportunity to analyze the quantitative and qualitative data separately, to explain the quantitative findings with qualitative results, and to use the qualitative results in order to fill the gaps that exist in 
our quantitative results [75]. Specific details about data collection, analysis, and results for each phase are presented below.

Phase I: Quantitative Data Collection and Analysis

\subsection{Participants and Procedures}

Respondents comprised employees and supervisors of SMEs working in the Limburg Province, the Netherlands. Using the European Union's definition, SMEs included companies that employed fewer than 250 employees. The validity of self-ratings is higher [76] and leniency effects are suppressed [77] when employees know that supervisors are also providing ratings. Participants held several job types, primarily at middle and higher positions, since more complex and non-routine professions allow greater opportunities for individual innovation [78]. Purposive selection was conducted based on sampling criteria, including a geographical representation of SMEs, the SMEs' various branches, and willingness of the company to improve the employability and the innovative work behaviors of their employees. Companies were approached through the researchers' personal contacts in the Limburg Province and the Employers Association for SMEs in Limburg (i.e., convenience sampling has been used). The sample consisted of 487 pairs of employees and their immediate supervisors working in 151 SMEs. Eighteen percent of the pairs (employees and their supervisor) worked in micro firms, $27 \%$ worked in small businesses, and 55\% worked in medium-sized enterprises.

For employees, $59.5 \%$ were men and $40.5 \%$ were women, and $52.4 \%$ of the employees were younger than 40 years old and $47.6 \%$ were older than or equal to 40 . The mean age of the employees was 38 years $(\mathrm{SD}=11.05)$, and the average length of service in the organization was 7.43 years $(\mathrm{SD}=5.51)$. Nearly $82 \%$ of supervisors were men and $18.1 \%$ were women, and the mean age of the supervisors was 43 years $(\mathrm{SD}=9.23)$.

An independent agency administered a web questionnaire under the researchers' supervision to ensure respondent anonymity and to mitigate social desirability. Participants received an anonymous response report showing their scores on the variables, interpretation guidelines, and a framework concerning ways to improve their future employability. The supervisors completed a questionnaire that consisted of amended items phrased to assess corresponding subordinates. To avoid collecting invalid information due to the training or fatigue of overburdened supervisors and to protect data independence, one supervisor completed ratings for a maximum of three employees [53]. To prevent common-method bias [79], data on employability, LMX, and perceived organizational politics were obtained from employees, and data on OCB and innovative work behaviors were obtained from immediate supervisors.

\subsection{Measures}

Quality of supervisor-employee relationship was measured using Graen, Novak, and Sommerkamp's LMX instrument [80]. Supervisor-employee relationships were assessed using a seven-item version of the instrument. Six items assessed leader-member relationships on three dimensions of trust ( 2 items), respect ( 2 items), and obligation ( 2 items), and one global item that addressed relationship quality. Participants scored items on a Likert-type scale that ranged from 1 (not at all) to 5 (extremely).

Organizational citizenship behaviors were measured using Podsakoff, MacKenzie, Moorman, and Fetter's [81] twenty-four item questionnaire based on the five dimensions of altruism (5 items), conscientiousness (5 items), sportsmanship (5 items), courtesy (5 items), and civic virtue (4 items). Participants rated these items on a Likert-type scale that ranged from 1 (strongly disagree) to 7 (strongly agree).

Innovative work behaviors were measured using a nine-item scale from Janssen [37,46], based on the three dimensions of idea generation ( 3 items), idea promotion ( 3 items), and idea realization ( 3 items). Items were scored using a Likert-type scale with responses ranging from 1 (never) to 7 (always). 
Employability was measured using a validated, five-dimensional scale from Van der Heijde and Van der Heijden $[17,19]$, including occupational expertise (15 items), anticipation and optimization (8 items), personal flexibility ( 8 items), corporate sense ( 7 items), and balance ( 9 items). The construct was measured using 47 items, with all items scored using a Likert-type scale that ranged from 1 (not at all/never) to 6 (considerable degree/very often), depending on an item's wording.

Perceptions of organizational politics were measured using Kacmar and Carlson's [82] instrument, which comprises three dimensions of general political behaviors ( 2 items), go along to get ahead (7 items), and pay and promotion policies (6 items). Items were scored using a Likert-type scale that ranged from 1 (strongly disagree) to 5 (strongly agree).

Measures for LMX and perceptions of organizational politics were originally constructed in English. The translation-back translation method was used to establish conformity of meaning and to optimize linguistic qualities [83]. The resulted Dutch translated scales were pretested using a sample of employees and managers in Limburg SMEs to validate the translation. For OCB [84], employability [17], and innovative work behaviors [46], existing validated translations were used.

\subsection{Preliminary Analyses}

All employability dimensions (self-ratings) demonstrated good internal consistency, with Cronbach's alpha coefficients ranging from 0.78 to 0.91 . Alpha coefficients for the LMX subscales (self-ratings) ranged from 0.69 to 0.76 . Coefficients for the OCB subscales (supervisor ratings) were 0.57 to 0.83 , and for perceptions of organizational politics (self-ratings), 0.65 to 0.82 . Innovative work behaviors subscales (supervisor ratings) also demonstrated good internal consistencies with Cronbach's alphas ranging from 0.90 to 0.92 . Inter-correlations among self-rated employability subscales ranged from 0.27 to $0.60(p<0.01)$; among self-rated LMX subscales these ranged from 0.56 to $0.70(p<0.01)$; among supervisor-rated OCB subscales these ranged from 0.35 to $0.62(p<0.01)$; among self-rated perceptions of organizational politics subscales these ranged from 0.30 to $0.57(p<0.01)$; and among supervisor-rated innovative work behaviors subscales these ranged from 0.77 to $0.81(p<0.01)$. Most employability dimensions (self-rated) correlated significantly with other model variables (53 out of 75 correlations); for self-rated LMX this applied to 60 out of 64 correlations; for supervisor-rated OCB this applied to 68 out of 75; for self-rated perceptions of organizational politics this applied to 43 out of 51; and for supervisor-rated innovative work behavior dimensions this applied to 42 of 51 (see Table 1). 
Table 1. Means, standard deviations, reliability coefficients, and correlations among model variables $(N=487)$.

\begin{tabular}{|c|c|c|c|c|c|c|c|c|c|c|c|c|c|c|c|c|c|c|c|c|c|c|c|}
\hline & & Mean & $S D$ & 1 & 2 & 3 & 4 & 5 & 6 & 7 & 8 & 9 & 10 & 11 & 12 & 13 & 14 & 15 & 16 & 17 & 18 & 19 & 20 \\
\hline & $\begin{array}{c}\text { Employability } \\
\text { six-point rating scale }\end{array}$ & 4.35 & 0.42 & 0.93 & & & & & & & & & & & & & & & & & & & \\
\hline 1 & $\begin{array}{c}\text { Occupational Expertise } \\
\text { (Self) }\end{array}$ & 4.68 & 0.48 & 0.91 & & & & & & & & & & & & & & & & & & & \\
\hline 2 & $\begin{array}{l}\text { Anticipation and } \\
\text { Optimization } \\
\text { (Self) }\end{array}$ & 3.90 & 0.68 & $0.36^{* *}$ & 0.84 & & & & & & & & & & & & & & & & & & \\
\hline 3 & Personal Flexibility (Self) & 4.46 & 0.51 & $0.50 * *$ & $0.57^{* *}$ & 0.78 & & & & & & & & & & & & & & & & & \\
\hline 4 & $\begin{array}{c}\text { Corporate Sense } \\
\text { (Self) }\end{array}$ & 4.11 & 0.66 & $0.48^{* *}$ & $0.60 * *$ & & & & & & & & & & & & & & & & & & \\
\hline \multirow[t]{2}{*}{5} & $\begin{array}{c}\begin{array}{c}\text { Balance } \\
\text { (Self) }\end{array} \\
\text { (S) }\end{array}$ & 4.27 & 0.61 & $0.35 * *$ & $0.27 * *$ & 0.35 ** & $0.31^{* *}$ & 0.84 & & & & & & & & & & & & & & & \\
\hline & $\begin{array}{l}\text { Leader-Member Exchange } \\
\text { five-point rating scale }\end{array}$ & 3.93 & 0.62 & 0.88 & & & & & & & & & & & & & & & & & & & \\
\hline 6 & $\begin{array}{c}\text { Respect } \\
\text { (Self) }\end{array}$ & 3.91 & 0.73 & $0.09^{* *}$ & $0.14 * *$ & 0.07 & $0.28 * *$ & $0.19 * *$ & 0.76 & & & & & & & & & & & & & & \\
\hline 7 & $\begin{array}{l}\text { Trust } \\
\text { (Self) }\end{array}$ & 4.03 & 0.68 & $0.12^{* *}$ & $0.16^{* *}$ & 0.07 & $0.30 * *$ & 0.22 ** & $0.70^{* *}$ & 0.69 & & & & & & & & & & & & & \\
\hline 8 & $\begin{array}{c}\begin{array}{c}\text { Obligation } \\
\text { (Self) }\end{array} \\
\text { (S) }\end{array}$ & 3.85 & 0.76 & 0.08 & $0.18 * *$ & 0.04 & $0.29 * *$ & $0.18^{* *}$ & $0.56^{* *}$ & $0.65 * *$ & 0.74 & & & & & & & & & & & & \\
\hline \multirow[t]{2}{*}{9} & $\begin{array}{l}\text { Relationship } \\
\text { (Self) }\end{array}$ & 3.95 & 0.77 & $0.15 * *$ & $0.22 * *$ & $0.15^{* *}$ & $0.29 * *$ & $0.26 * *$ & $0.57^{* *}$ & $0.60 * *$ & 0.58 ** & & & & & & & & & & & & \\
\hline & $\begin{array}{l}\text { Organizational Citizenship } \\
\text { Behaviors } \\
\text { seven-point rating scale }\end{array}$ & 5.44 & 0.69 & 0.90 & & & & & & & & & & & & & & & & & & & \\
\hline 10 & $\begin{array}{c}\text { Altruism } \\
\text { (Supervisor) }\end{array}$ & 5.59 & 0.77 & 0.06 & $0.15 *$ & $0.18^{* *}$ & $0.22 * *$ & 0.20 ** & 0.31 ** & $0.30 * *$ & 0.30 ** & $0.36^{* *}$ & 0.83 & & & & & & & & & & \\
\hline 11 & $\begin{array}{c}\text { Conscientiousness } \\
\text { (Supervisor) }\end{array}$ & 5.31 & 0.83 & 0.05 & $0.11^{* *}$ & $0.11^{* *}$ & $0.17^{* *}$ & 0.02 & $0.25 * *$ & $0.25 * *$ & $0.24 * *$ & $0.26^{* *}$ & $0.51^{* *}$ & 0.57 & & & & & & & & & \\
\hline 12 & $\begin{array}{l}\text { Sportsmanship } \\
\text { (Supervisor) }\end{array}$ & 5.50 & 1.11 & $0.10^{*}$ & 0.05 & 0.18 ** & 0.07 & $0.17^{* *}$ & $0.27 * *$ & $0.21 * *$ & 0.20 ** & $0.26^{* *}$ & $0.55^{* *}$ & 0.35 ** & 0.82 & & & & & & & & \\
\hline 13 & $\begin{array}{c}\text { Courtesy } \\
\text { (Supervisor) }\end{array}$ & 5.36 & 0.85 & 0.01 & 0.09 & $0.10^{*}$ & $0.12 * *$ & $0.12^{* *}$ & $0.25 *$ & $0.21^{* *}$ & 0.26 ** & $0.31^{* *}$ & $0.59^{* *}$ & $0.52^{* *}$ & $0.53 * *$ & 0.73 & & & & & & & \\
\hline \multirow[t]{2}{*}{14} & $\begin{array}{l}\text { Civic Virtue } \\
\text { (Supervisor) }\end{array}$ & 5.45 & 0.88 & $0.09 *$ & $0.22 * *$ & $0.21^{* *}$ & $0.26 *$ & $0.13^{* *}$ & $0.24 *$ & $0.26^{* *}$ & 0.30 ** & $0.34 *$ & $0.62^{* *}$ & $0.54^{* *}$ & $0.45 * *$ & 0.55 ** & 0.76 & & & & & & \\
\hline & $\begin{array}{l}\text { Perceptions of } \\
\text { Organizational Politics } \\
\text { five-point rating scale }\end{array}$ & 2.40 & 0.53 & 0.83 & & & & & & & & & & & & & & & & & & & \\
\hline 15 & $\begin{array}{c}\text { General Political Behaviors } \\
\text { (Self) }\end{array}$ & 2.25 & 0.95 & 0.06 & 0.02 & 0.06 & -0.02 & -0.14 & -0.30 & -0.33 & $\underset{\substack{* \\
* *}}{-0.34}$ & -0.33 & -0.25 & -0.15 & -0.20 & $\underset{* *}{-0.21}$ & -0.26 & 0.73 & & & & & \\
\hline 16 & $\begin{array}{l}\text { Go Along to Get Ahead } \\
\text { (Self) }\end{array}$ & 2.29 & 0.66 & -0.09 & -0.16 & -0.11 & -0.29 & -0.22 & -0.40 & -0.46 & -0.46 & -0.43 & $\underset{* *}{-0.30}$ & -0.26 & -0.23 & -0.25 & -0.31 & $0.57^{* *}$ & 0.82 & & & & \\
\hline
\end{tabular}


Table 1. Cont

\begin{tabular}{|c|c|c|c|c|c|c|c|c|c|c|c|c|c|c|c|c|c|c|c|c|c|c|c|}
\hline & & Mean & $S D$ & 1 & 2 & 3 & 4 & 5 & 6 & 7 & 8 & 9 & 10 & 11 & 12 & 13 & 14 & 15 & 16 & 17 & 18 & 19 & 20 \\
\hline \multirow[t]{2}{*}{17} & $\begin{array}{l}\text { Pay and Promotion Policies } \\
\text { (Self) }\end{array}$ & 2.57 & 0.59 & $-0.09 *$ & $-0.10^{*}$ & $-0.11 *$ & $\begin{array}{c}-0.16 \\
* *\end{array}$ & -0.27 & $\underset{* *}{-0.30}$ & $\underset{* *}{-0.32}$ & $\begin{array}{c}-0.30 \\
* *\end{array}$ & $\underset{* *}{-0.24}$ & $\underset{* *}{-0.22}$ & $\underset{* *}{-0.16}$ & $\underset{* *}{-0.22}$ & $\underset{* *}{-0.21}$ & $\underset{* *}{-0.20}$ & 0.30 ** & $0.36^{* *}$ & 0.65 & & & \\
\hline & $\begin{array}{l}\text { Innovative Work Behaviors } \\
\text { seven-point rating scale }\end{array}$ & 3.45 & 1.14 & 0.95 & & & & & & & & & & & & & & & & & & & \\
\hline 18 & $\begin{array}{l}\text { Idea Generation } \\
\text { (Supervisor) }\end{array}$ & 3.52 & 1.10 & 0.04 & $0.18^{* *}$ & $0.14 * *$ & $0.23^{* *}$ & 0.02 & $0.18^{* *}$ & 0.22 ** & $0.24 * *$ & $0.25 * *$ & $0.38^{* *}$ & $0.29 * *$ & $0.23^{* *}$ & $0.31^{* *}$ & $0.51^{* *}$ & $\underset{* *}{-0.16}$ & $\underset{* *}{-0.18}$ & -0.08 & 0.90 & & \\
\hline 19 & $\begin{array}{l}\text { Idea Promotion } \\
\text { (Supervisor) }\end{array}$ & 3.52 & 1.26 & -0.02 & 0.20 ** & $0.12 * *$ & $0.22 * *$ & 0.04 & $0.20^{* *}$ & $0.21^{* *}$ & $0.24 *$ & $0.29 * *$ & $0.44^{* *}$ & $0.32^{* *}$ & $0.23 * *$ & $0.32 * *$ & $0.51^{* *}$ & $\underset{* *}{-0.21}$ & $\underset{* *}{-0.23}$ & -0.07 & $0.79 * *$ & 0.92 & \\
\hline 20 & $\begin{array}{l}\text { Idea Realization } \\
\text { (Supervisor) }\end{array}$ & 3.33 & 1.32 & 0.04 & $0.19^{* *}$ & $0.10^{* *}$ & $0.18^{* *}$ & 0.04 & $0.18^{* *}$ & $0.22 * *$ & $0.24 * *$ & $0.26^{* *}$ & $0.40^{* *}$ & $0.32^{* *}$ & $0.19^{* *}$ & $0.32 * *$ & $0.51^{* *}$ & $\underset{* *}{-0.15}$ & $\underset{* *}{-0.19}$ & -0.08 & $0.77^{* *}$ & $0.81^{* *}$ & 0.90 \\
\hline
\end{tabular}

Note. Cronbach's alpha coefficients on the diagonal. ${ }^{*} p<0.05 ;{ }^{* *} p<0.01$. 


\subsection{Pair-Wise Comparisons}

Since a considerable number of combined ratings were collected from both employees and immediate supervisors, i.e., employability, LMX, OCB, and innovative work behaviors, comparisons between scale means for the two groups were possible. Cronbach's alpha coefficients for these constructs showed that, with the exception of the balance subscale for employability and all LMX subscales, in each case the supervisor alpha coefficients were higher in comparison to the corresponding self-ratings. Moreover, paired-samples t-tests confirmed that for each employability dimension, self-ratings were higher than supervisor ratings, though the balance subscale's correlation was non-significant. For each LMX and OCB dimension, self-ratings were significantly higher in comparison with their supervisor ratings. Contrarily, for each innovative work behaviors dimension self-ratings were lower than supervisor ratings, with the pair-wise difference pertaining to the subscale idea generation being non-significant. Hetero, paired-samples comparisons were made and correlations between each pair ranged from 0.25 to $0.32(p<0.001)$ for employability, from 0.21 to $0.36(p<0.001)$ for LMX, 0.19 to 0.33 $(p<0.001)$ for OCB (subscale courtesy was non-significant), and 0.28 to $0.33(p<0.001)$ for innovative work behaviors. All inter-method correlations were positive (see Table 2). According to Cronbach [85], the convergence of two indicators on the same scale supports the validity of both.

Table 2. Employee (Self) versus supervisor ratings: Cronbach's alpha coefficients, paired-samples $t$-tests and paired-samples correlations; self-ratings $(N=487)$ and supervisor ratings $(N=487)$.

\begin{tabular}{|c|c|c|c|c|c|}
\hline & $\begin{array}{c}\text { Mean } \\
\text { Self/Supervisor }\end{array}$ & $\begin{array}{c}S D \\
\text { Self/Supervisor }\end{array}$ & $\begin{array}{l}\text { Cronbach's Alphas } \\
\text { Self/Supervisor }\end{array}$ & $t$-Value & $r$ \\
\hline \multicolumn{6}{|l|}{ Employability } \\
\hline Occupational Expertise & $4.68 / 4.51$ & $0.48 / 0.67$ & $0.91 / 0.95$ & $5.29 * * *$ & $0.25^{* * *}$ \\
\hline Anticipation and Optimization & $3.90 / 3.77$ & $0.68 / 0.78$ & $0.84 / 0.90$ & $3.37^{* *}$ & $0.32 * * *$ \\
\hline Personal Flexibility & $4.46 / 4.23$ & $0.51 / 0.69$ & $0.78 / 0.88$ & $6.64^{* * *}$ & $0.25^{* * *}$ \\
\hline Corporate Sense & $4.11 / 4.01$ & $0.66 / 0.78$ & $0.79 / 0.87$ & $2.49^{*}$ & $0.30^{* * *}$ \\
\hline Balance & $4.27 / 4.24$ & $0.61 / 0.56$ & $0.84 / 0.83$ & 1.05 & $0.32^{* * *}$ \\
\hline \multicolumn{6}{|l|}{ Leader-Member Exchange } \\
\hline Respect & $3.91 / 3.78$ & $0.73 / 0.64$ & $0.76 / 0.68$ & $3.19^{* *}$ & $0.21^{* * *}$ \\
\hline Trust & $4.03 / 3.95$ & $0.68 / 0.63$ & $0.69 / 0.57$ & $2.50 *$ & $0.27 * * *$ \\
\hline Obligation & $3.85 / 3.76$ & $0.76 / 0.76$ & $0.74 / 0.67$ & $2.06 *$ & $0.29^{* * *}$ \\
\hline Relationship & $3.95 / 3.86$ & $0.77 / 0.74$ & $-/-$ & $2.34 *$ & $0.36^{* * *}$ \\
\hline \multicolumn{6}{|l|}{ Organizational Citizenship } \\
\hline \multicolumn{6}{|l|}{ Behaviors } \\
\hline Altruism & $5.87 / 5.59$ & $0.59 / 0.77$ & $0.68 / 0.83$ & $7.03^{* * *}$ & $0.19^{* * *}$ \\
\hline Conscientiousness & $5.58 / 5.31$ & $0.70 / 0.83$ & $0.48 / 0.57$ & $6.54 * * *$ & $0.29^{* * *}$ \\
\hline Sportsmanship & $5.84 / 5.50$ & $0.77 / 1.11$ & $0.66 / 0.82$ & $6.39 * * *$ & $0.26^{* * *}$ \\
\hline Courtesy & $5.60 / 5.36$ & $0.73 / 0.85$ & $0.64 / 0.73$ & $4.89^{* * *}$ & 0.05 \\
\hline Civic Virtue & $5.70 / 5.45$ & $0.77 / 0.88$ & $0.68 / 0.76$ & $5.72 * * *$ & $0.33^{* * *}$ \\
\hline \multicolumn{6}{|l|}{ Innovative Work Behaviors } \\
\hline Idea Generation & $3.44 / 3.52$ & $0.98 / 1.10$ & $0.82 / 0.90$ & -1.40 & $0.33^{* * *}$ \\
\hline Idea Promotion & $3.28 / 3.52$ & $1.07 / 1.26$ & $0.85 / 0.92$ & $-3.67^{* *}$ & $0.28^{* * *}$ \\
\hline Idea Realization & $3.06 / 3.33$ & $1.10 / 1.32$ & $0.83 / 0.90$ & $-4.06^{* * *}$ & $0.30^{* * *}$ \\
\hline
\end{tabular}

\subsection{Structural Equation Modelling}

To establish a parsimonious SEM that included relationships among LMX, OCB, innovative work behaviors, employability, and perceived organizational politics, we tested a baseline model and modified four subsequent models based on their results. The strengths of relationships among constructs within the distinguished models were also considered, as well as guided choices regarding inclusion or exclusion of paths in subsequent models. Maximum-likelihood estimation of covariance matrices was used during all SEM analyses, and model fit was assessed using three indices-normed chi-square $\left(\chi^{2} / \mathrm{df}\right)$, root mean square error of approximation (RMSEA), and the goodness of fit index (GFI). A GFI greater than 0.90 and a RMSEA less than 0.08 indicate an adequate fit between the model 
and data [86]. Subscale scores for the dimensions of each construct were used as estimates of latent constructs instead of raw scores for individual items [87].

Before testing structural relationships among model variables, we established that the latent variables represented distinct constructs. Three of the constructs (i.e., LMX, employability, and perceived organizational politics) were self-measures captured from employees, and two (i.e., OCB and innovative work behavior) were captured from employees' immediate supervisors. To test both convergent and discriminant validity, a confirmatory factor analysis (CFA) using SEM was conducted. Again, scale scores were used as estimates of latent construct indicators. Results of the CFA suggest both convergent and discriminant validity. Chi-square/df was 2.832, RMSEA was 0.061, and GFI was 0.913 .

\subsection{Model Tests}

Model 1 was a baseline model that tested H1a, H1b, H2a, and H2b. The model suggests that both LMX and OCB correlate with employability and innovative work behaviors. Another SEM tested whether alternative models were warranted. H3 suggests that employability correlates positively with innovative work behaviors (Model 2). A separate SEM tested whether the relationship exists absent of complications by testing other relationships in the same model. $\mathrm{H} 4 \mathrm{a}$ and $\mathrm{H} 4 \mathrm{~b}$ suggest that employability partially or fully mediates LMX and OCB on the one hand and the endogenous construct innovative work behaviors on the other hand. Model 3, the partially mediated model, was tested with employability as a mediator and included direct effects between both LMX/OCB and innovative work behaviors. Model 4 was identical to Model 3 except that direct effects were removed, indicating full mediation by the employability variable. Models 3 and 4 were compared using two criteria: first, results from SEM analyses were compared to determine which model offered a more parsimonious fit, and second, beta coefficients for relationships among constructs were examined in both models to determine which model accounted for more explained variance when predicting work innovative behaviors. From these criteria, either Model 3 or 4 was chosen as a baseline for Model 5 .

Model 5 tested H5. Moderation analyses using SEM is difficult since there exists no observable data to estimate a moderating latent construct [88]. Some approaches in the literature produce unmanageable SEMs [89], resulting in models that can be estimated but with great ambiguity during their interpretation. This is especially a problem since this study builds on both alternative modelling and model-generation techniques; in other words, the ability to contrast models was paramount to the study's purpose. Based on recommendations from [89], we used an unconstrained approach to construct observable variables and to estimate an interaction term-a latent (moderating) variable. First, an exploratory factor analysis (varimax rotation, eigenvalues $>1$ ) was conducted using the five variables that estimated the employability construct and the three variables that estimated the perceived organizational politics construct as latent factors. Factor loadings from the analysis were ordered in descending magnitude, and the top three employability variables were paired with the perceived organizational politics variables according to magnitude. The employability variable with the highest magnitude was multiplied by the perceived organizational politics variable with the highest magnitude to create a variable to estimate interaction. The same was done for the second and third highest magnitude factor loadings. The result was three observed variables, serving as estimates for the latent moderator variable (i.e., the product of employability and perceived organizational politics).

Phase II: Qualitative Data Collection and Analysis

\subsection{Participants and Procedures}

In-depth interviews (standardized open-ended interviews) and a focus group explained and complemented the quantitative results, aimed at examining the complexities of SME employees' and supervisors' experiences of the antecedents and outcomes of employability. Criterion sampling was used to select participants for the interviews and the focus group. In phenomenological studies, the criterion is that participants must have experienced the phenomena being studied [74]. For the in-depth interviews, five SME supervisors participated (S1-S5) and in the focus group two SME employees (E1; 
E2) and six SME supervisors (S6-S11) participated. Our interview questions focused on participants' lived experiences of perspective-taking, sustainable innovation, development of skills (being an important ingredient of employability), and perceived organizational politics. Sample questions regarding RQ1 included, "What is your experience with relating or empathizing with others in the workplace?" and "What is your experience with the support of your supervisor regarding your innovative work behaviors?" and "Do your employees perform extra activities?" and if so, "What kind of activities do they perform?"

Sample questions regarding RQ2 included, "What is your experience with the ability to empathize with others and because of this, the enhancement of social skill development?" and "Do you experience that employees with adequate skills and competences (hence: employability) contribute to sustainable innovation?" and if so, "Why?" and if not, "Why not?"

Sample questions regarding RQ3 included, "What is your experience with organizational politics?" and "Do you have any experience with a negative working atmosphere?" and if so, "How did this negative working atmosphere influences innovative working behaviors?"

\subsection{Data Analysis}

First of all, our standardized open-ended interviews and focus group were recorded and fully transcribed. We used descriptive coding to label and organize data that pertained to the variables in our study. Next, we used pattern coding to cluster statements and segments of the interviews according to descriptive codes to identify themes, causes/explanations, and relationships between our variables. After that we conducted mapping to determine how they interrelate. During pattern coding and mapping, we used memoing to capture spontaneous ideas and thoughts about data [90]. Individual narratives representing each participant's experiences were constructed; included in the narrative were the structures, meanings, and essences of each experience. Using themes developed from the pattern coding, mapping, and memoing, effects matrices were created to depict the antecedents and outcomes of employability [90].

\section{Results}

Phase 1: Quantitative Study

Results for Model 1 suggest good fit; the chi-square/df was 3.091, RMSEA 0.066, and GFI 0.918 (see Table 3), and the beta coefficients supported H1b, H2a, and H2b. However, H1a was not supported with our data. Although H1a was not supported, we continued with subsequent analyses. More specifically, the correlation between OCB and innovative work behaviors was strong, thus OCBs might have accounted for such a large amount of variance that no variance remained for LMX to explain innovative work behaviors. Since both relationships were removed in Model 4, results from the baseline model were adequate to continue with subsequent analyses (see Figure 2).

Table 3. Structural equation analysis results for all models.

\begin{tabular}{ccccccc}
\hline Model & $N$ & $d f$ & $\chi^{2}$ & $\chi^{2} / d f$ & RMSEA & GFI \\
\hline Null Model for Model 1 & 487 & 136 & 4148.967 & 30.507 & 0.246 & 0.371 \\
1. Baseline Model & 487 & 114 & 352.361 & 3.091 & 0.066 & 0.918 \\
2. Employability/Innovative Work Behaviors & 487 & 19 & 91.951 & 4.840 & 0.089 & 0.957 \\
3. Partial Mediation & 487 & 113 & 350.886 & 3.105 & 0.066 & 0.919 \\
4. Full Mediation & 487 & 115 & 475.556 & 4.135 & 0.080 & 0.900 \\
5. Moderator & 487 & 163 & 869.965 & 5.337 & 0.094 & 0.856 \\
\hline
\end{tabular}




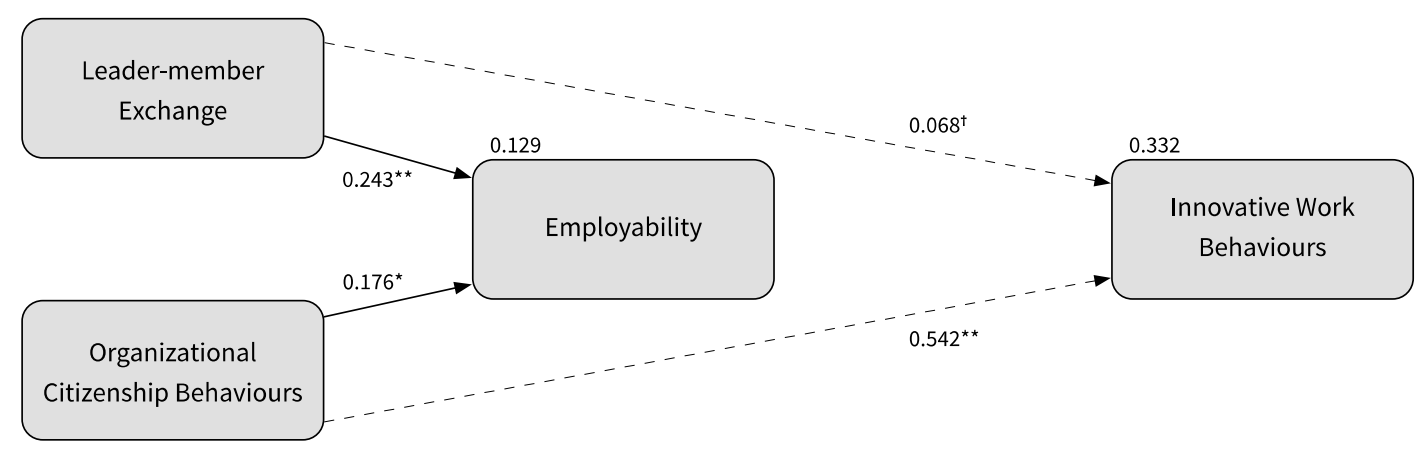

Figure 2. Baseline Model (Model 1). ${ }^{*} p<0.01 ;{ }^{* *} p<0.001 ;{ }^{\dagger} \mathbf{n} / \mathbf{s}$.

Model 2 tested H3 and results suggest a good fit; the chi-square/df was 4.840, RMSEA 0.089, and GFI 0.957. The beta coefficient was significant, so H3 was supported with our data (see Figure 3). Model 3 was an elaboration of the baseline model (Model 1), with the relationship that was found in Model 2 incorporated. Model 3 comprised a partially mediated model since the direct relationships between both LMX and OCB were included, with innovative work behaviors also being included. Results suggest a good fit; the chi-square/df was 3.150, RMSEA 0.066, and GFI 0.919. The relationship between LMX and innovative work behaviors was non-significant. The significant relationship between employability and innovative work behaviors that was found in Model 2 was not found in Model 3, and hence H4a was not supported with our data. Similarly, H4b was not supported either (see Figure 4).

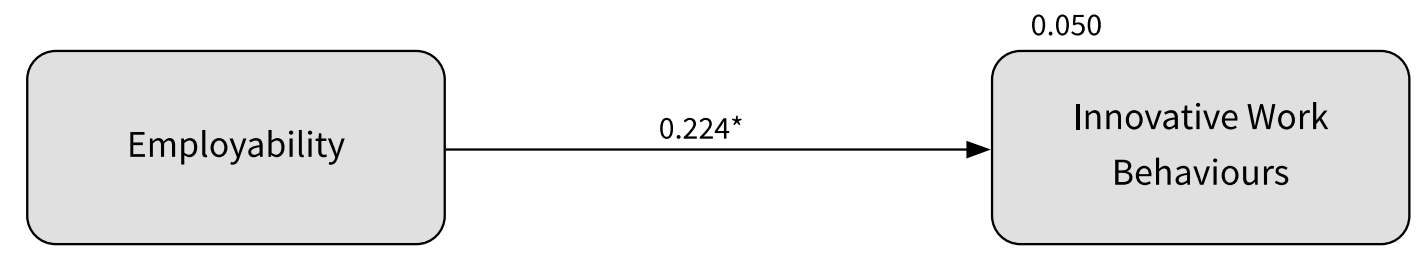

Figure 3. Employability and innovative work behaviors (Model 2). ${ }^{*} p<0.001$.

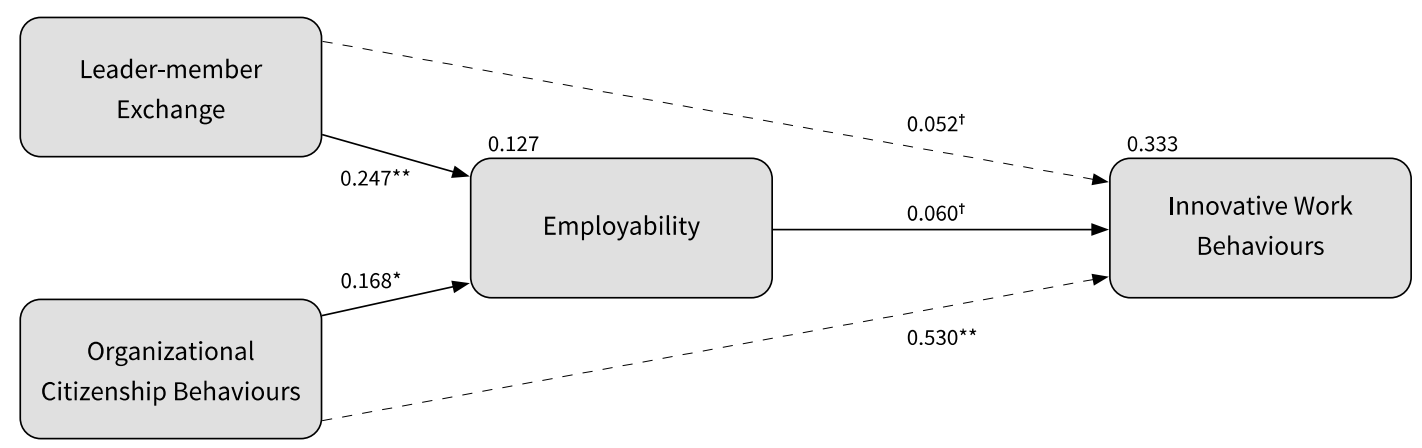

Figure 4. Partially mediated model (Model 3). ${ }^{*} p<0.01 ;{ }^{* *} p<0.001 ;{ }^{\dagger} \mathrm{n} / \mathrm{s}$.

Results suggest that Model 4 had a good fit; the chi-square/df was 4.135, RMSEA 0.080, and GFI 0.900. Unlike the outcomes for Model 3, the relationship between employability and innovative work behaviors was significant, therefore supporting H4a and H4b. In comparison to Model 4, Model 3 provided a more parsimonious fit, and its fit indices were superior. However, all of Model 4's relationships were significant, and we concluded that the practical implication of choosing a model with all hypothesized relationships being significant, rather than global measures of fit, represents a better contribution to the literature. Consequently, Model 4, the fully mediated model, was chosen as the preferred model for Model 5 (see Figure 5). 


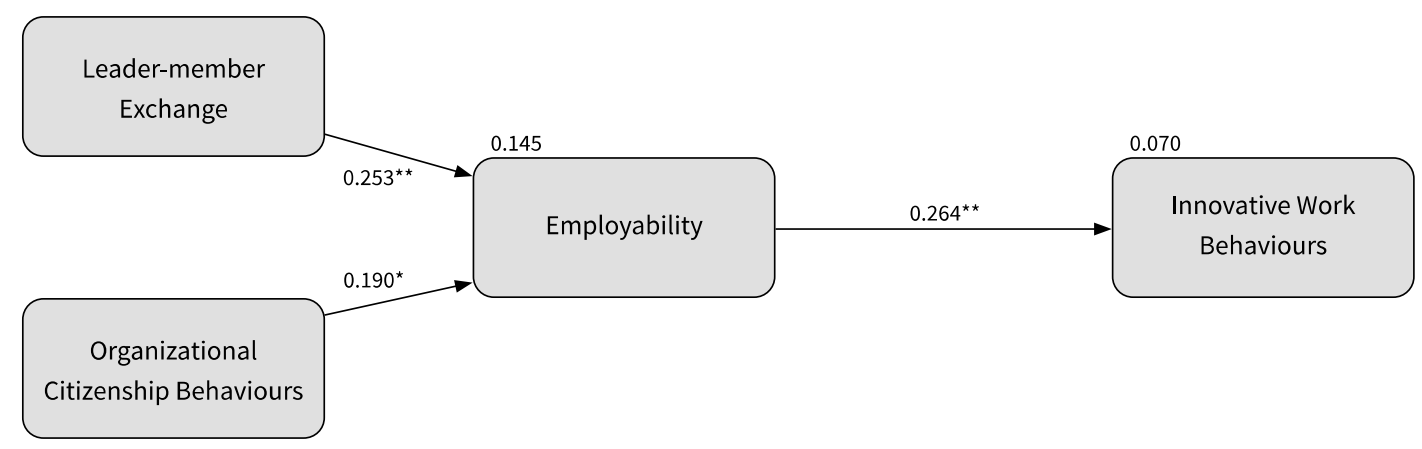

Figure 5. Fully mediated model (Model 4). ${ }^{*} p<0.01 ;{ }^{* *} p<0.001$.

Model 5 was identical to Model 4 except that perceived organizational politics moderated employability and innovative work behaviors. Results suggest a moderate fit and a negative moderation effect. The chi-square/df was 5.337, RMSEA 0.094, and GFI 0.856. Although the results were less impressive than those for Model 4, all hypothesized relationships were significant, and hence H5 was supported with our data (see Figure 6).

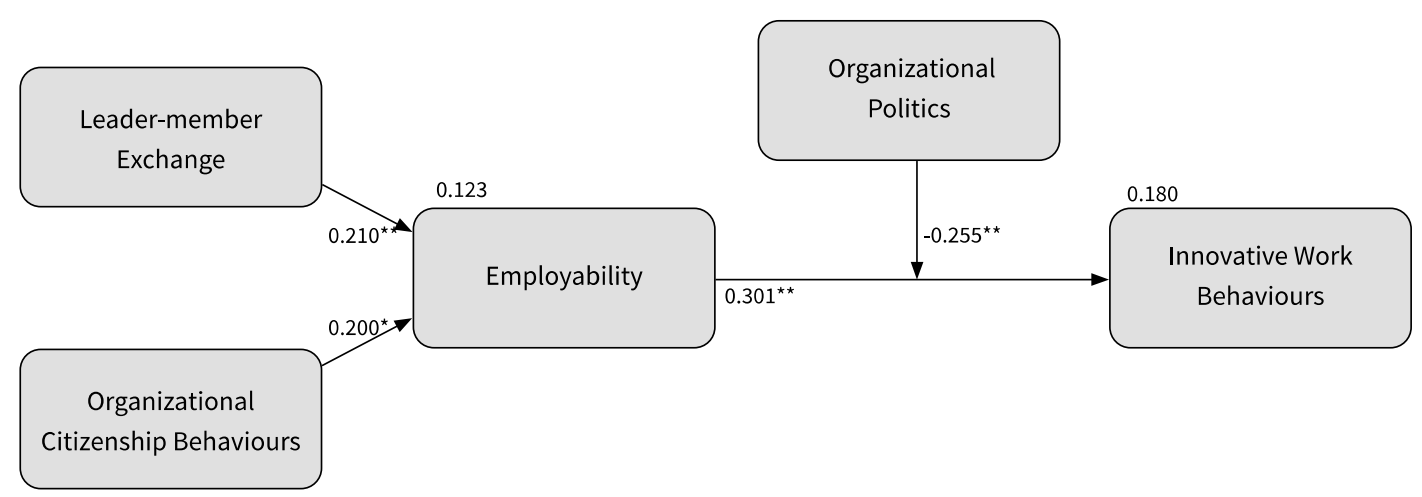

Figure 6. Moderated model (Model 5). ${ }^{*} p<0.01 ;{ }^{* *} p<0.001$.

To summarize, all relationships in the fully mediated model were significant and this model was more favorable given the comparison with the outcomes from the partially mediated model. Consequently, employability appears to be a variable that fully mediates the relationship between LMX and OCB, on one hand, and innovative work behaviors on the other hand. Moreover, perceived organizational politics negatively moderated the relationship between employability and innovative work behaviors.

Phase 2: Qualitative Study

The qualitative findings are organized and presented below, categorized into three areas: (a) the experiences of participants (employees and supervisors of SMEs) as regards to the importance of the ability to relate to others (perspective-taking), for instance to one's supervisor (LMX), or the importance to engage in extra-role behaviors $(\mathrm{OCB})$, and their effect on sustainable innovation within the organization; (b) participants' experiences with the ability to empathize with someone else and to see things from their perspective (perspective-taking) and because of this, the development of social competences and skills (being an important ingredient of employability), and whether this also contributes to innovative work behaviors; (c) participants' experiences with organizational politics and their possible harmful impact on innovation efforts, as well as the impact of a negative work atmosphere and a suboptimal learning climate on knowledge, skill development, and sustainable innovation.

A summary of the themes and exemplary quotations related to each of these three areas are included in Tables 4-6, respectively. 
Table 4. Themes and exemplary quotes related to participants' experiences of LMX, OCB, and sustainable innovation.

\begin{tabular}{|c|c|}
\hline Themes & Exemplary Quotes \\
\hline Ability to relate to another & $\begin{array}{l}\text { "If you can't put yourself in a situation, you can't see why someone is doing } \\
\text { certain things" (S8) } \\
\text { "I can imagine that a technician can't reflect on my work and doesn't exactly } \\
\text { know what I'm doing" (S6) } \\
\text { "You both have a different role, with different interests, different information, so } \\
\text { there might always be a difference in what you think or experience" (S9) } \\
\text { "If you totally understand each other, there will be an atmosphere of kindness and } \\
\text { sweetness. Then nothing will change, ever" (E1) } \\
\text { "If my supervisor would communicate what she needs, then I can think along } \\
\text { with her" (E1) }\end{array}$ \\
\hline LMX & $\begin{array}{l}\text { "A supervisor telling me what to do and how to do it, that is not my forte" (E1) } \\
\text { "Everyone has their own responsibility, and although I keep my eye on it, I am } \\
\text { not on top of it" (S2) } \\
\text { "I give employees the flexibility to do their job" (S1) } \\
\text { "We also do nice things together" (S3) }\end{array}$ \\
\hline OCB & $\begin{array}{l}\text { "We always help each other; we are just one team. And if one cannot manage, } \\
\text { someone else will step in and take over" (S2) } \\
\text { "What do I get back when I'm doing extra?" (E1) } \\
\text { "It needs to be relaxed, feel good about yourself. That vibe also glows } \\
\text { outside" (S2) }\end{array}$ \\
\hline Sustainable innovation & $\begin{array}{l}\text { "Sometimes, employees come up with revolutionary ideas that might be brilliant } \\
\text { but simply do not fit. That is a tricky one because it is simply not possible. That is } \\
\text { very difficult to explain" (S7) } \\
\text { "They come up with new ideas, and from there we try to do something with } \\
\text { it" (S5) }\end{array}$ \\
\hline LMX on sustainable innovation & $\begin{array}{l}\text { "Just to say, I was thinking and so I did it ... That is something we don't } \\
\text { appreciate. Before you know it, it is a mess in here with people just doing } \\
\text { whatever they feel like. But employees who come up with ideas, yeah, that } \\
\text { happens" S4 } \\
\text { "I see a lot of things, but I don't do any of them, because my supervisor doesn't } \\
\text { say anything" E1 } \\
\text { "Letting go is one of the hardest things to do" S6 }\end{array}$ \\
\hline OCB on sustainable innovation & $\begin{array}{l}\text { "It is the same work, at a different moment, better suited with the customer" (S1) } \\
\text { "Doing extra doesn't lead to new innovations. We are too busy to think about } \\
\text { innovation" (S7) } \\
\text { "Within a very innovative organization, one of the employees was an advisor, but } \\
\text { he was also incredibly creative. In the evening, at home, he was inventing all } \\
\text { kinds of visual support tools, which he and other advisors introduced to } \\
\text { clients" (S9) }\end{array}$ \\
\hline
\end{tabular}

Table 5. Themes and exemplary quotes related to participants' experiences of the relationship between LMX, OCB, and employability and sustainable innovation.

\begin{tabular}{cl}
\hline Employability & $\begin{array}{l}\text { "We coach each other, but the employees here don't } \\
\text { attend formal training very often" (S3) }\end{array}$ \\
\hline "Education and development are very important to \\
me, so facilitate that for me" (E1) \\
"I have had just a few employees who were willing to \\
follow training and seminars. I have always found \\
that quite disappointing" (S7) \\
"My idea is that people who are busy at work also do \\
the most outside of it" (S7)
\end{tabular}


Table 6. Themes and exemplary quotes related to participants' experiences of the moderating effect of organizational politics.

\begin{tabular}{ll}
\hline & "It actually plays no role here, because they know \\
& each other so well" S2 \\
"Owners of an SME are often not aware of the great \\
effect they have on the organization, on the behaviors \\
of employees. That is much greater than they \\
themselves think" A1 \\
"It destroys a lot of people" S8 \\
"Next time an employee thinks: I will not do my \\
utmost anymore" A2 \\
"It has to do with security: when you don't feel safe, \\
you don't want to put extra effort in it, or take risks to \\
improve your" E1
\end{tabular}

(a) Ability to relate to others: All of the participants believe that it is important to relate to others and to have the ability to perceive someone else's thoughts, feelings, and motivations, although some hold the opinion that truly understanding the other is not always possible or worth pursuing when sustainable innovation is the objective. "If you totally understand each other, there will be an atmosphere of kindness and sweetness. Then nothing will change, ever" (E1). Understanding each other stimulates innovative work behaviors. It helps employees to think in the interest of the supervisor/organization. "If my supervisor would communicate what she needs, then I can think along with her" (E1). If a manager takes the needs of the employee into consideration, the employee is willing to go the extra mile (OCB). "I think it is a matter of give and take. If you give something, people will give you something in return" (S3).

Participants' experiences with LMX: Most supervisors claim that they perform activities in order to develop, nurture, and sustain the relationship with their employees. These activities vary from an outdoor activity to flexibility during the working day. They set a clear goal and leave it up to the employee to work towards it. Both employees and supervisors state that there is a difference between leaders who are specific about the goal and leaders who specify the way it should be achieved. "Everyone has their own responsibility, and although I keep my eye on it, I am not on top of it" (S2). The relationship between the supervisor and employee might change over time. "When an organization grows, the owner grows into a new, more transformational style" (S9).

Participants' experiences with OCB: Most participants say that employees are willing to do extra activities. Some of those activities come within their formal role requirements. Others go beyond their duties. Activities within the formal role requirements include the performance of the same work, but at a different time that is more appropriate for the customer or doing the same work but taking longer to complete it. "We always help each other; we are just one team. And if one cannot manage, someone else will step in and take over" (S2). Extra activities beyond role requirements are, for instance, helping a junior colleague, coaching, or answering specific questions.

Participants' experiences with sustainable innovation: All the participants have examples of employees who demonstrate innovative work behaviors. Supervisors mention that not all (the employees) come up with behaviors that are relevant to the organization. They mention that it is difficult to be critical about an idea and keep the employee motivated at the same time. "Sometimes, employees come up with revolutionary ideas that might be brilliant but simply do not fit. That is a tricky one because the implementation of such a particular idea is simply not possible. That is very difficult to explain" (S7).

Influence of LMX on sustainable innovation: Supervisors reflect on and explain the results of our quantitative research where no direct relationship has been found between LMX and employee's innovative behaviors. Before an employee shows innovative behavior, consultation with the supervisor is expected. "Just to say 'I was thinking and so I did it ... That is something we don't always appreciate. Before you know it, it is a mess in here with people just doing whatever they feel like. But employees 
who come up with ideas, yeah, that happens" (S4). Employees like mutual consultation before showing innovative work behaviors. "I see a lot of things, but I don't do any of them, because my supervisor doesn't say anything" (E1). So, employees' behaviors in line with the strategy of the organization seems to be relevant. And when the relationship between supervisor and employee is positive, it will lead to more interaction and dialogue.

Influence of OCB on sustainable innovation: Participants make a big difference between working hard and performing extra work within the role requirements and going beyond the role requirements. Simply working extra hard but doing the same thing does not lead to sustainable innovation. Quite the opposite, in fact: It is hard to be innovative when working so hard. It is the performance of extra activities beyond role requirements that leads to sustainable innovation. "Within a very innovative organization, one of the employees was an advisor, but he was also incredibly creative. In the evening, at home, he was inventing all kinds of visual support tools, which he and other advisors introduced to clients" (S9).

(b) Participants' experiences with employability: Participants value the importance of the development of social competences and skills (being an important ingredient of employability). In SMEs, such development mostly takes place informally within the context of the organization. "We coach each other, but the employees here don't attend formal training very often" (S3).

Influence of OCB and LMX on employability: Participants see it as the supervisor's task to facilitate the development of skills and knowledge. A good supervisor provides employees with opportunities to develop and stay employable. "Education and development are very important to me, so facilitate that for me" (E1). Although it seems to be disappointing for supervisors that so few employees are willing to follow additional education or training. "I have had just a few employees who were willing to follow training and seminars. I have always found that quite disappointing" (S7). An employee who is willing to walk the extra mile is usually more consciously focused on their own employability. "My idea is that people who are busy at work, also do the most outside of it" (S7). Extra activities beyond role requirements are, for example, helping a junior colleague or answering questions. "An accountant helping a junior colleague, even though his own production drops, develops new skills. He learns to explain, to order his thoughts and insights and thereby becomes a real senior" (S8).

Influence of employability on sustainable innovation: Participants sometimes see employability and sustainable innovation as inseparable, and therefore value the results of the quantitative part of our study. "These terms go together. If you are innovative, then you are employable. And employable employees are innovative" (S7). On the other hand, some small firms are based on a craft and, therefore, are not innovative. "It is a craft that we do. You can't learn this in the classroom. We perform at a very high level, but we can't innovate much: it still is largely manual work" (S4).

(c) The moderating effect of organizational politics on the influence of employability on sustainable innovation: Most supervisors who participated appear to interact with employees who have worked for them for a long time and in small teams. The employees know each other very well, so politics are not an issue. "It actually plays no role here, because they know each other so well" (S2). Some participants have a different opinion: "Owners of an SME are often not aware of the great effect they have on the organization, on the behaviors of employees. That is much greater than they themselves think" (S9). All participants consider politics as negative because the person involved in politics is only self-interested and not interested in organizational goals. Organizational politics demotivate other employees to try new things because nobody appreciates them. "They destroy the ideas of a lot of people" (S8). "Next time an employee thinks: I will not do my utmost anymore" (S10). Not only politics but also an unconstructive atmosphere has a negative effect on the relationship between employability and innovative work behaviors. "A negative atmosphere costs so much energy, that you have no energy left for innovation" (S9). "It has to do with security: when you don't feel safe, you don't want to put extra effort in it, or take risks to improve your work" (E1). 


\section{Discussion and Integration of Qualitative and Quantitative Findings}

\subsection{Employee versus Supervisor Ratings}

In the quantitative part of this study, 487 pairs of combined ratings were collected from both employees and immediate supervisors, allowing noteworthy comparisons to be made between these two groups of respondents. Cronbach's alpha coefficients for the employability, LMX, OCB, and innovative work behavior constructs demonstrated that, with the exception of the balance subscale for employability and all LMX subscales, all supervisor reliability coefficients were higher in comparison to the corresponding self-ratings. It appears that the ratings from employees reveal a reliable and valid - though more differentiated—self-image. The halo effect [91] might be a possible explanation for these outcomes. Extant studies indeed suggested that the halo effect is not as prominent in self-ratings as in corresponding supervisor ratings [92]. It is very interesting to note that the supervisor coefficients of LMX were lower in comparison to the corresponding self-ratings. This outcome supports the previously mentioned explanation that self-ratings are more differentiated; in our case pertaining to assessment of leadership qualities of the supervisors themselves.

Outcomes from the paired-samples t-tests for employability, LMX, and OCB indicated that for each subscale self-ratings were higher than the corresponding supervisor ones, although the difference in means for the balance dimension for employability was not significant. The tendency for employees to be relatively more positive about themselves (leniency effect) [77] was found in our data as well. Rating discrepancies might also be explained by the fact that supervisors judge employee performance and behaviors relatively more harshly; that is to say, the hardiness effect may be an explanatory factor as well $[17,93]$.

\subsection{Towards a Mediation Model of Innovative Work Behaviors Enhancement}

Although some progress is apparent in the literature [25], research into competency antecedents (e.g., employability) for innovative work behaviors has been sparse. The benefits of maintaining close relationships and high-quality exchanges between employee and supervisor (LMX), and individual development as a result of employees' discretionary behaviors (OCB) influence innovative work behaviors directly through its positive effects on workers' employability. Since management practices in SMEs are largely informal [94] and financial resources for educational programs are limited [95], our qualitative findings revealed that a mix of formal and informal learning opportunities are encouraged. Organizations that invest in their employees sustain competitive advantage $[95,96]$. Close relationships and high-quality exchanges, particularly in SMEs that are characterized by shorter communication lines and less hierarchical distance [20], provide more space, freedom, and trust for displaying discretionary behaviors that enhance workers' career potential and therefore increase the possibility of engaging in innovative work behaviors [97].

With these outcomes, we add to the work by Witt [8], who argued that employees' partly socially-shaped cognitive frames, as a result of sound cognitive leadership, and to the work by Erkut [9] who posited the importance of nudging, that is giving employees responsibility for increasing their occupational competencies, as antecedents for innovative work behaviors. Obviously, the latter are of utmost importance in the light of entrepreneurial success (ibid). In particular, our study indicates that high-quality interactions between employees and their supervisors, and extra-role behaviors of subordinates, strengthen their innovative work behaviors directly and as a result of their augmented career potential (i.e., their employability). As such, this study helps to unravel the process through which leadership in SMEs can help to foster innovative behaviors.

In addition, this study contributes to earlier work on a better understanding of the social dimension in relation to organizational sustainability by disentangling the possible role of organizational politics. Politics interfere with innovation [71,72]. In particular, current results suggest that organizational politics moderate employability and innovative work behaviors negatively. Bodla and Danish [98] argue that various performance variables correlate with perceptions of organizational politics, but 
relationships differ across occupations and are higher in public positions. This study suggests that in SMEs that span various branches, the relationship between employability and innovative work behaviors is positive, suggesting a close relationship that, given the outcomes of our empirical work, appears to be susceptible to the negative effects of politics.

\subsection{Limitations and Future Research}

This study was cross-sectional; research that uses longitudinal designs that test causal and reciprocal effects are needed to examine the role of time in the model. The model was tested using one convenience sample drawn from one province in the Netherlands, and therefore external validity is limited since the sample was not representative of the SME population in this particular country and across the globe. To investigate the generalizability of outcomes, additional samples of SMEs are required. In addition, future research should link the model variables not only to individual, but also meso- and macro-level performance outcomes. Investigations that examine team and organizational performance would suggest whether individual work-related factors influence higher-level outcomes. Moreover, organizational politics could also be treated as a moderator in the relationship between other antecedents and work-related outcomes such as employability. Witt and Spector [99] argue that employee personalities influence both perceptions of and reactions to organizational politics, yet little research so far links personality and individual differences [100] to perceived organizational politics.

\subsection{Practical Implications}

In knowledge-based economies such as that in the Netherlands where SMEs comprise more than $99 \%$ of all enterprises, $64 \%$ of employment, and $62 \%$ of value added [101], highly skilled employees are essential [64]. Keeping with the trend of the increasing numbers of smaller firms, the need for effective SME management practices is crucial [102]. This study offers a better understanding of the relationships among the variables used in the model and is meant to make members of the working population aware of the dysfunctional effect of perceived organizational politics. Since our qualitative results suggest that organizational politics are common, practitioners should invest in preventing their detrimental effects [66] and focus on supporting organizational goals that are intended to increase positive work outcomes. Small firms do not often employ professional HR managers [103]; SME supervisors frequently develop their own models of what are good management practices. It is of utmost importance that supervisors, in close consultation with independent HR specialists, become aware of the antecedents of the growth and added value of their human capital and how employees' sustainable competences [104] and self-empowerment [9] can be enhanced. According to Erkut [9], self-empowerment is an important predictor of innovative behaviors and can be accomplished by nudging, defined as "any aspect of the choice architecture that alters people's behavior in a predictable way without forbidding any options or significantly changing their economic incentives" [105] (p. 6). As financial resources in SMEs are limited, we also emphasize the importance of informal learning opportunities for employees, beyond formal ones, that allow supervisors to contribute to an optimal learning climate within SMEs. These practices will enhance employees' growth and enrichment and, as such, contribute to the Sustainable Development Goals (see also [106]).

Author Contributions: Conceptualization, J.S. and B.v.d.H.; Methodology, J.S., B.v.d.H. and I.S.; Software, J.S.; Validation, J.S. and B.v.d.H.; Formal analysis, J.S., B.v.d.H. and I.S.; Investigation, J.S., B.v.d.H. and I.S.; Resources, J.S.; Data curation, J.S. and I.S.; Writing-original draft preparation, J.S., B.v.d.H. and I.S.; Writing-review and editing, J.S., B.v.d.H. and I.S.; Visualization, J.S.; Supervision, J.S.; Project administration, J.S. All authors have read and agreed to the published version of the manuscript.

Funding: This research received no external funding.

Conflicts of Interest: The authors declare no conflict of interest. 


\section{References}

1. De Jong, J.P.J.; Den Hartog, D.N. Measuring innovative work behaviour. Creat. Innov. Manag. 2010, 19, $23-26$. [CrossRef]

2. Xie, Y.; Xue, W.; Li, L.; Wang, A.; Chen, Y.; Zheng, Q.; Wang, Y.; Li, X. Leadership style and innovation atmosphere in enterprises: An empirical study. Technol. Forecast. Soc. Chang. 2018, 135, 257-265. [CrossRef]

3. United Nations. About the Sustainable Development Goals. Available online: https://www.un.org/ sustainabledevelopment/sustainable-development-goals/ (accessed on 5 December 2019).

4. Duradoni, M.; Di Fabio, A. Intrapreneurial self-capital and sustainable innovative behavior within organizations. Sustainability 2019, 11, 322. [CrossRef]

5. Amabile, T.M. How to kill creativity. Harv. Bus. Rev. 1998, 76, 77-87.

6. Yi, L.; Uddin, M.; Das, A.K.; Mahmood, M.; Sohel, S.M. Do transformational leaders engage employees in sustainable innovative work behaviour? Perspective from a developing country. Sustainability 2019, 11, 2485. [CrossRef]

7. Kim, W.; Park, J. Examining structural relationships between work engagement, organizational procedural justice, knowledge sharing, and innovative work behavior for sustainable organizations. Sustainability 2017, 9, 205. [CrossRef]

8. Witt, U. Imagination and leadership-the neglected dimension of an evolutionary theory of the firm. J. Econ. Behav. Organ. 1998, 35, 161-177. [CrossRef]

9. Erkut, B. Perceiving Innovation: Who 'Makes' SAP Labs India and How? South Asian J. Bus. Manag. Cases 2016, 5, 116-125. [CrossRef]

10. Stoffers, J.M.M.; Van der Heijden, B.I.J.M. Towards an HRM model predicting organizational performance by enhancing innovative work behaviour: A study among Dutch SMEs in the province of Limburg. Bus. Leadersh. Rev. 2009, 6, 1-13.

11. Parker, S.K.; Axtell, C.M. Seeing another viewpoint: Antecedents and outcomes of employee perspective-taking. Acad. Manag. J. 2001, 44, 1085-1100.

12. Galinsky, A.D.; Moskowitz, G.B. Counterfactuals as behavioural primes: Priming the simulation heuristic and consideration of alternatives. J. Exp. Soc. Psychol. 2000, 36, 384-409. [CrossRef]

13. Galinsky, A.D.; Wang, C.S.; Ku, G. Perspective-takers behave more stereotypically. J. Pers. Soc. Psychol. 2008, 95, 404-419. [CrossRef] [PubMed]

14. Barile, S.; Saviano, M.; Landolo, F.; Calabrese, M. The viable systems approach and its contribution to the analysis of sustainable business behaviors. Syst. Res. Behav. Sci. 2014, 31, 683-695. [CrossRef]

15. Florea, L.; Cheung, Y.H.; Herndon, N.C. For all good reasons: Role of values in organizational sustainability. J. Bus. Ethics 2013, 114, 393-408. [CrossRef]

16. Davis, M.H. Measuring individual differences in empathy: Evidence for a multidimensional approach. J. Pers. Soc. Psychol. 1983, 44, 113-126. [CrossRef]

17. Van der Heijde, C.M.; Van der Heijden, B.I.J.M. A competence-based and multidimensional operationalization and measurement of employability. Hum. Resour. Manag. 2006, 45, 449-476. [CrossRef]

18. Van der Heijden, B.; Notelaers, G.; Peters, P.; Stoffers, J.; De Lange, A.; Froehlich, D.; Van der Heijde, C. Development and validation of the short-form employability five-factor instrument. J. Vocat. Behav. 2018, 106, 236-248. [CrossRef]

19. Van der Heijden, B.I.; Gorgievski, M.J.; De Lange, A.H. Learning at the workplace and sustainable employability: A multi-source model moderated by age. Eur. J. Work Organ. Psychol. 2016, 25, 13-30. [CrossRef]

20. Van der Heijden, B.I.J.M. Als het Getij Verloopt, Verzet men de Bakens [Inaugural Lecture on Life-long Employability Management]; Radboud University Nijmegen: Nijmegen, The Netherlands, 2011.

21. Graen, G.B.; Scandura, T. Toward a psychology of dyadic organizing. In Research in Organizational Behavior; Cummings, L.L., Staw, B.M., Eds.; JAI Press: Greenwich, CT, USA, 1987; pp. 175-208.

22. Volmer, J.; Spurk, D.; Niessen, C. Leader-member exchange (LMX), job autonomy, and creative work involvement. Leadersh. Q. 2011, 23, 456-465. [CrossRef]

23. Naqshbandi, M.M.; Kaur, S. A study of organizational citizenship behaviours, organizational structures and open innovation. Int. J. Bus. Soc. Sci. 2011, 2, 182-193. [CrossRef] 
24. Organ, D.W. Organizational Citizenship Behavior: The Good Soldier Syndrome; Lexington Books: Lexington, MA, USA, 1988.

25. De Clippeleer, I.; De Stobbeleir, K.; Dewettinck, K.; Ashford, S. From Creativity to Success: Barriers and Critical Success Factors in the Successful Implementation of Creative Ideas; (Research Report); Vlerick Leuven Gent Management School: Leuven, Belgium, 2009.

26. De Jong, J.P.J.; Den Hartog, D.N. How leaders influence employees' innovative behaviour. Eur. J. Innovat. Manag. 2007, 10, 41-64. [CrossRef]

27. Stoffers, J.M.M.; Van der Heijden, B.I.J.M.; Notelaers, G.L.A. Towards a moderated mediation model of innovative work behaviour enhancement. J. Organ. Chang. Manag. 2014, 27, 642-659. [CrossRef]

28. Stoffers, J.M.M.; Van der Heijden, B.I.J.M.; Jacobs, E.A.G.M. Employability and innovative work behaviour in small and medium-sized enterprises. Int. J. Hum. Resour. Manag. 2018, 29, 1-28. [CrossRef]

29. Weissenberger-Eibl, M.A.; Teufel, B. Organizational politics in new product development project selection: A review of the current literature. Eur. J. Innovat. Manag. 2011, 14, 51-73. [CrossRef]

30. Shoham, A.; Vigoda-Gadot, E.; Ruvio, A.; Schwabsky, N. Testing an organizational innovativeness integrative model across cultures. J. Eng. Technol. Manag. 2012, 29, 226-240. [CrossRef]

31. Schyns, B.; Day, D. Critique and review of leader-member exchange theory: Issues of agreement, consensus, and excellence. Eur. J. Work Organ. Psychol. 2010, 19, 1-29. [CrossRef]

32. Graen, G.B.; Uhl-Bien, M. Relationship-based approach to leadership: Development of leader-member exchange (LMX) theory of leadership over 25 years: Applying a multi-level multi-domain perspective. Leadersh. Q. 1995, 6, 219-247. [CrossRef]

33. Liden, R.C.; Sparrowe, R.T.; Wayne, S.J. Leader-member exchange theory: The past and potential for the future. Res. Pers. Hum. Resour. Manag. 1997, 15, 119-147.

34. Yildiz, S.M. An empirical analysis of the leader-member exchange and employee turnover intentions mediated by mobbing: Evidence from sport organisations. Econ. Res. Ekonomska Istraživanja 2018, 31, 480-497. [CrossRef]

35. Fairhurst, G.T. Discursive Leadership: In Conversation with Leadership Psychology; Sage: Thousand Oaks, CA, USA, 2007.

36. Miron, E.; Erez, M.; Naveh, E. Do personal characteristics and cultural values that promote innovation, quality, and efficiency compete or complement each other? J. Organ. Behav. 2004, 25, 175-199. [CrossRef]

37. Janssen, O. Job demands, perceptions of effort-reward fairness, and innovative work behaviour. J. Occup. Organ. Psychol. 2000, 73, 287-302. [CrossRef]

38. Sanders, K.; Moorkamp, M.; Torka, N.; Groeneveld, S.; Groeneveld, C. How to support innovative behaviour? The role of LMX and satisfaction with HR practices. Technol. Invest. 2010, 1, 59-68. [CrossRef]

39. Podsakoff, P.M.; MacKenzie, S.B.; Paine, J.B.; Bachrach, D.G. Organizational citizenship behaviors: A critical review of the theoretical and empirical literature and suggestions for future research. J. Manag. 2000, 26, 513-563. [CrossRef]

40. Podsakoff, P.M.; MacKenzie, S.B. Impact of organizational citizenship behavior on organizational performance: A review and suggestions for future research. Hum. Perform. 1997, 10, 133-151. [CrossRef]

41. Boiral, O.; Paillé, P. Organizational citizenship behavior for the environment: Measurement and validation. J. Bus. Ethics 2012, 109, 431-445. [CrossRef]

42. Lamm, E.; Tosti-Kharas, J.; Williams, E.G. Read this article, but don't print it: Organizational citizenship behavior toward the environment. Group Organ. Manag. 2013, 38, 163-197. [CrossRef]

43. Lengnick-Hall, C.A. Innovation and competitive advantage: What we know and what we need to learn. J. Manag. 1992, 18, 399-429. [CrossRef]

44. Van de Ven, A.H. Central problems in the management of innovation. Manag. Sci. 1986, 32, $590-607$. [CrossRef]

45. Farr, J.; Ford, C.; West, M.; Farr, J. Individual innovation. In Innovation and Creativity at Work; John Wiley and Sons: Chichester, UK, 1990.

46. Janssen, O. Fairness perceptions as a moderator in the curvilinear relationships between job demands, and job performance and job satisfaction. Acad. Manag. J. 2001, 44, 1039-1050.

47. Amabile, T.M.; Conti, R.; Coon, H.; Lazenby, J.; Herron, M. Assessing the work environment for creativity. Acad. Manage J 1996, 39, 1154-1184. 
48. Hedge, J.W.; Borman, W.C.; Lammlein, S.E. The Aging Workforce: Realities, Myths, Implications for Organizations; American Psychological Association: Washington, DC, USA, 2006.

49. Rothwell, A.; Arnold, J. Self-perceived employability: Development and validation of a scale. Pers. Rev. 2007, 36, 23-41. [CrossRef]

50. De Cuyper, N.; Bernhard-Oettel, C.; Berntson, E.; DeWitte, H.; Alarco, B. Employability and employees' well-being: Meditation by job insecurity. Appl. Psychol. Int. Rev. 2008, 57, 488-509. [CrossRef]

51. Fugate, M.; Kinicki, A.J. A dispositional approach to employability: Development of a measure and test of implications for employee reactions to organizational change. Occup. Organ. Psychol. 2008, 81, 503-527. [CrossRef]

52. Van der Heijden, B.I.J.M.; De Lange, A.H.; Demerouti, E.; Van der Heijden, C.M. Employability and career success across the life-span. Age effects on the employability-career success relationship. J. Vocat. Behav. 2009, 74, 156-164. [CrossRef]

53. Van der Heijden, B.I.J.M. The development and psychometric evaluation of a multi-dimensional measurement instrument of professional expertise. High Ability Stud. 2000, 11, 9-39.

54. Fugate, M.; Kinicki, A.J.; Ashforth, B.E. Employability a psycho-social construct, its dimensions, and applications. J. Vocat. Behav. 2004, 65, 14-38. [CrossRef]

55. Howell, J.M.; Hall-Meranda, K.E. The ties that bind: The impact of leader-member exchange, transformational and transactional leadership, and distance on predicting follower performance. J. Appl. Psychol. 1999, 84, 650-694. [CrossRef]

56. Van der Heijden, B.I.J.M.; Scholarios, D.; Bozionelos, N.; Van der Heijden, C.M.; Epitropaki, O. Indic@tor Report: A Cross-Cultural Study on the Measurement and Enhancement of Employability in Small and Medium-Sized ICT-Companies; European Commission: Brussels, Belgium, 2005.

57. Spitzmuller, M.; Van Dyne, L.; Ilies, R. Organizational citizenship behavior: A review and extension of its nomological network. In The SAGE Handbook of Organizational Behavior; Barling, J., Cooper, C.L., Eds.; Sage: Thousand Oaks, CA, USA, 2008; pp. 106-123.

58. Penner, L.A.; Dovidio, J.F.; Piliavin, J.A.; Schroeder, D.A. Prosocial behavior: Multilevel perspectives. Ann. Rev. Psychol. 2005, 56, 365-392. [CrossRef]

59. George, J.M.; Brief, A.P. Feeling good-doing good: A conceptual analysis of the mood at work-organizational spontaneity relationship. Psychol. Bull. 1992, 112, 310-329. [CrossRef]

60. Delaney, J.T.; Huselid, M.A. The impact of human resource management practices on perceptions of organizational performance. Acad. Manag. J. 1996, 39, 949-969.

61. Guthrie, J.P.; Liu, W.; Flood, P.C.; MacCurtain, S. High Performance Work Systems, Workforce Productivity, and Innovation: A Comparison of MNCs and Indigenous Firms. Available online: https://core.ac.uk/ download/pdf/147597618.pdf (accessed on 5 December 2019).

62. Kandampully, J. Innovation as the core competency of a service organisation: The role of technology, knowledge and networks. Eur. J. Innovat. Manag. 2002, 5, 18-26. [CrossRef]

63. Youndt, M.A.; Snell, S.A.; Dean, J.W.; Lepak, D.P. Human resource management, manufacturing strategy and firm performance. Acad. Manag. J. 1996, 39, 836-867.

64. Stoffers, J.M.M.; Van der Heijden, B.I.J.M. An innovative work behaviour-enhancing employability model moderated by age. Eur. J. Train. Dev. 2018, 42, 143-163. [CrossRef]

65. Zhang, Q.; Sun, S.; Zheng, X.; Liu, W. The role of cynicism and personal traits in the organizational political climate and sustainable creativity. Sustainability 2019, 11, 257. [CrossRef]

66. Ferris, G.R.; Treadway, D.C. Politics in Organizations: Theory and Research Considerations; Routledge: New York, NY, USA, 2012.

67. Parker, C.P.; Dipboye, R.L.; Jackson, S.L. Perceptions of organizational politics: An investigation of antecedents and consequences. J. Manag. 1995, 21, 891-912. [CrossRef]

68. Ferris, G.R.; Frink, D.D.; Galang, M.C.; Zhou, J.; Kacmar, M.K.; Howard, J.L. Perceptions of organizational politics: Prediction, stress-related implications, and outcomes. Hum. Relat. 1996, 49, 233-266. [CrossRef]

69. Ferris, G.R.; Russ, G.S.; Fandt, P.M. Politics in organizations. In Impression Management in the Organization; Giacalone, R.A., Rosenfeld, P., Eds.; Lawerence Erlbaum: Hillsdale, NJ, USA, 1989; pp. 143-170.

70. West, M.A.; Wallace, M. Innovation in health care teams. Eur. J. Soc. Psychol. 1991, 21, 303-315. [CrossRef]

71. Frost, P.J.; Egri, C.P.; Cummings, L.L.; Staw, B.M. The political process of innovation. In Research in Organizational Behaviour; Staw, B.M., Cummings, L.L., Eds.; JAI Press: Greenwich, CT, USA, 1991; pp. 229-295. 
72. Vigoda-Gadot, E.; Vashdi, D.R. Politics in and around teams: Toward a team-level conceptualization of organizational politics. In Politics in Organizations: Theory and Research Considerations; Ferris, G.R., Treadway, D.C., Eds.; Routledge: New York, NY, USA, 2012; pp. 287-322.

73. Ellström, P.E. Practice-based innovation: A learning perspective. J. Workplace Learn. 2010, 22, 27-40. [CrossRef]

74. Creswell, J.W.; Plano Clark, V.L. Designing and Conducting Mixed Methods Research; Sage: Thousand Oaks, CA, USA, 2010.

75. Ivankova, N.V.; Creswell, J.W.; Stick, S.L. Using mixed-methods sequential explanatory design: From theory to practice. Field Methods 2006, 18, 3-20. [CrossRef]

76. Mabe, P.; West, S. Validity of self-evaluation of ability: A review and meta-analysis. J. Appl. Psychol. 1982, 67, 280-296. [CrossRef]

77. Arnold, J.; MacKenzie Davis, K. Self-ratings and supervisor-ratings of graduate employees' competences during early career. J. Occup. Organ. Psychol. 1992, 65, 235-250. [CrossRef]

78. Scott, S.G.; Bruce, R.A. Determinants of innovative behavior: A path model of individual innovation in the workplace. Acad. Manag. J. 1994, 37, 580-607.

79. Podsakoff, P.M.; MacKenzie, S.B.; Lee, J.Y.; Podsakoff, N.P. Common methods bias in behavioral research: A critical review of the literature and recommended remedies. J. Appl. Psychol. 2003, 88, 879-903. [CrossRef] [PubMed]

80. Graen, G.B.; Novak, M.; Sommerkamp, P. The effect of leader-member exchange and job design on productivity and satisfaction: Testing a dual attachment model. Organ. Behav. Hum. Perform. 1982, 30, 109-131. [CrossRef]

81. Podsakoff, P.M.; MacKenzie, S.B.; Moorman, R.H.; Fetter, R. Transformational leader behaviors and their effects on followers' trust in leader, satisfaction, and organizational citizenship behaviors. Leadersh. Q. 1990, 1, 107-142. [CrossRef]

82. Kacmar, M.; Carlson, C. Further validation of the perceptions of politics scale (POPS): A multiple sample investigation. J. Manag. 1997, 23, 627-658. [CrossRef]

83. Hambleton, R.K. Guidelines for adapting educational and psychological test: A progress report. Eur. J. Psychol. Assess. 1994, 10, 229-244.

84. De Clercq, S.; Fontaine, J.R.J.; Anseel, F. In search of a comprehensive value model for assessing supplementary person-organization fit. J. Psychol. 2008, 142, 277-302. [CrossRef]

85. Cronbach, L.J. Essentials of Psychological Testing; HarperCollins: New York, NY, USA, 1990.

86. Browne, M.W.; Cudeck, R. Alternative ways of assessing model fit. In Testing Structural Equation Models; Bollen, K.A., Long, J.S., Eds.; Sage: Newbury Park, CA, USA, 1993; pp. 136-162.

87. Coffman, D.L.; MacCallum, R.C. Using parcels to convert path analysis models into latent variable models. Multivar. Behav. Res. 2005, 40, 235-259. [CrossRef]

88. Hayduk, L.A. Structural Equation Modeling with LISREL: Essentials and Advances; Johns Hopkins University: Baltimore, MD, USA, 1987.

89. Marsh, H.W.; Wen, Z.; Hau, K.T. Structural equation models of latent interaction and quadratic effects. In Structural Equation Modeling: A Second Course; Hancock, G.R., Mueller, R.O., Eds.; Information Age: Greenwich, CT, USA, 2006; pp. 225-265.

90. Miles, M.B.; Huberman, A.M. Qualitative Data Analysis; Sage: Thousand Oaks, CA, USA, 1994.

91. Hoffman, C.C.; Nathan, B.R.; Holden, L.M. A comparison of validation criteria: Objective versus subjective performance measures and self versus supervisor ratings. Pers. Psychol. 1991, 44, 601-619. [CrossRef]

92. Van der Heijden, B.I.J.M.; Verhelst, N.D. The psychometric evaluation of a multi-dimensional measurement instrument of professional expertise: Results from a study in small and medium-sized enterprises in the Netherlands. Eur. J. Psychol. Assess. 2002, 18, 165-178. [CrossRef]

93. Cole, M.S.; Bruch, H.; Vogel, B. Emotion as mediators of the relations between perceived supervisor support and psychological hardiness on employee cynicism. J. Organ. Behav. 2006, 27, 463-484. [CrossRef]

94. Wognum, A.A.M.; Bartlett, K.R. An examination of HRD in response to strategic learning needs in SMEs. Int. J. Hum. Resour. Dev. Manag. 2002, 2, 170-186. [CrossRef]

95. Müller, J.M.; Buliga, O.; Voigt, K.I. Fortune favors the prepared: How SMEs approach business model innovations in Industry 4.0. Technol. Forecast. Soc. Chang. 2018, 132, 2-17. [CrossRef] 
96. Nazir, S.; Qun, W.; Hui, L.; Shafi, A. Influence of social exchange relationships on affective commitment and innovative behavior: Role of perceived organizational support. Sustainability 2018, 10, 4418. [CrossRef]

97. Bysted, R. Innovative employee behaviour. The moderating effects of mental involvement and job satisfaction on contextual variables. Eur. J. Innovat. Manag. 2013, 16, 268-284. [CrossRef]

98. Bodla, M.A.; Danish, R.Q. The perceptions of organisational politics and work performance: Exploring the differences in public and private sector. Int. J. Knowl. Cult. Chang. Manag. 2008, 8, 123-131. [CrossRef]

99. Witt, L.A.; Spector, P.E. Personality and reactions to organizational politics. In Politics in Organizations: Theory and Research Considerations; Ferris, G.R., Treadway, D.C., Eds.; Routledge: New York, NY, USA, 2012; pp. 555-588.

100. Treadway, D.C.; Ferris, G.R.; Hochwarter, W.A.; Perrewe, P.L.; Witt, L.A.; Goodman, J.M. The role of age in the perceptions of politics-job performance relationship: A three-study constructive replication. J. Appl. Psychol. 2005, 90, 872-881. [CrossRef]

101. European Union. European Commission: SBA Fact Sheet 2018; European Commission: Brussels, The Netherlands, 2018.

102. Audretsch, D.B.; Thurik, A.R. What's new about the new economy? Form the managed to the entrepreneurial economy. Ind. Corp. Chang. 2001, 10, 267-315. [CrossRef]

103. Hornsby, J.S.; Kuratko, D.F. Human resource management in U.S. small business: A replication and extension. J. Dev. Entrep. 2003, 8, 73-92.

104. Wals, A.E.; Schwarzin, L. Fostering organizational sustainability through dialogic interaction. Learn. Organ. 2012, 19, 11-27. [CrossRef]

105. Thaler, R.H.; Sunstein, C.R. Nudge: Improving Decisions about Health, Wealth and Happiness; Yale University Press: New Haven, CT, USA; London, UK, 2008.

106. Di Fabio, A. The psychology of sustainability and sustainable development for well-being in organizations. Front. Psychol. 2017, 8, 1534. [CrossRef] [PubMed]

(C) 2019 by the authors. Licensee MDPI, Basel, Switzerland. This article is an open access article distributed under the terms and conditions of the Creative Commons Attribution (CC BY) license (http://creativecommons.org/licenses/by/4.0/). 